\title{
Influence of a Company's Social Initiatives on the Consumer Attitude towards It. Results of Experimental Research
}

\author{
Marek Pawlak', Grzegorz Zasuwa'
}

\begin{abstract}
This article constitutes an attempt to answer the question whether social initiatives undertaken by a company influence the consumer attitude towards it. The afore-mentioned aim has been achieved by presenting the results of experimental research. Six scenarios of social initiatives undertaken by a food sector company were used in the research. Research work was conducted using a sample of real consumers. It was shown that information about undertaking a single social initiative by a company does not lead to a more favourable consumer attitude towards it. The results obtained show that when undertaking a social programme, which is not consistent with the company's actions to date, the attitude towards it can even become worse.
\end{abstract}

KEY WORDS: $\quad$ consumer behaviour, corporate social initiatives, corporate attitudes

JEL Classification: M31

${ }^{1}$ The John Paul II Catholic University of Lublin, Poland

\section{Introduction}

Contemporary companies implement various social initiatives (Kotler \& Lee, 2004, p. 16). Such actions are often taken not only to provide support to beneficiaries of these programmes, but also to bring benefits to companies. Such treatment of social initiatives has led to what is considered as a change of the paradigm from "doing good for the good itself" to "doing good for mutual benefits" (Smith, 2003). In this new paradigm of social responsibility, social initiatives are treated in a way similar to traditional investments and they are expected to bring business benefits (Vogel, 2005, p. 19).

Benefits for companies in connection with undertaken social initiatives can be considered by analysing reactions of various stakeholders (Bhattacharya, Ko-

Corespondence concerning to this article should be addressed to: gzasuwa@kul.lublin.pl rchun \& Sen, 2009, p. 260). Undoubtedly, consumers are one of the most important stakeholder groups for a company.

Research concerning consumer reactions to corporate social initiatives is a relatively new field of study. Foreign publications on this subject began to appear in the second half of the 1990s. In the afore-mentioned studies, it was primarily attempted to prove that the implementation of social programmes brings about favourable consumer reactions, such as a more favourable attitude towards the company (e.g. Becker - Olsen, Cudmore \& Hill, 2006), higher consumer loyalty (e.g. Salmones, Crespo \& Bosque, 2005), or a high purchase intent (e.g. Lafferty \& Goldsmith, 1999). However, research has shown that favourable reactions do not always occur and sometimes social programmes can even bring effects opposite to the intended ones (e.g. Yoon, Gürhan - Kanli, 2003). In other words, it turned out that the achievement of business benefits from such programmes is difficult. 

American university centres (Sen, Bhattacharya \& Korschun, 2006).

It is worth underlining that Sen \& Bhattacharya (2001, p. 238) also discovered a "kind of symmetry" in consumer reactions to information about the social responsibility of companies. They showed that a company's evaluation made by consumers was more sensitive to negative than to positive information, even if the negative opinion results from not taking pro-social actions. The afore-mentioned asymmetry was also confirmed by Mohr \& Webb (2005) in their research on social initiatives of footwear sector companies. It was, in particular, proved that persons, to whom descriptions of a company with a low level of social responsibility were presented, evaluated such a company at a significantly lower level than the control group (the control group respondents did not receive any information about CRS). On the other hand, a comparison of the group, to which a scenario of a company with a high level of social responsibility was presented with a control group, did not show significant differences in the company's evaluation (Mohr \& Webb, 2005). Such results confirm the observations made by S. Sen $\&$ C.B. Bhattachary and they proved that negative information about a company's social responsibility has a greater influence on consumer reactions than positive information of this kind.

The studies discussed so far have indicated that there exists a positive relationship between undertaking social initiatives by companies and their evaluation made by consumers. It turns out, however, that pro-social activity may also be received in a negative way by consumers. This interesting problem was examined by Y. Yoon with her partners. This author analysed the relationship between the company's existing reputation, the level of the adjustment of the social programme, source of information about the social initiative and the company's evaluation. To examine the dependence between the variables listed above, three experimental studies were performed. Two of the studies used descriptions of fictitious companies and real stories from the activities of BP and Exon Groups were used in the third study. The research revealed that consumers were suspicious of a company if its pro-social activity contrasts with its reputation to date. For instance, if a company has caused an ecological disaster on sea and at the same time, it informs about its involvement in the protection of natural environment. Additionally, consumer suspicion increases if the company itself informs about such actions. In this case, pro-social initiatives undertaken by a company are perceived only as auto-promotion and lead to a lower evaluation of such a company (Yoon, Gürhan-Canli \& Schwarz, 2006).

It is also worth noting that, as the literature review shows, probably not all social initiatives have the same influence on consumer attitudes. This is shown, among other things, by research Prisch, Gupta \& Grau (2007), in which it was proven that institutional programmes lead to a more favourable consumer attitude towards the company than promotional initiatives. Institutional programmes were defined as long-term activities (lasting for several years) aimed at fulfilling obligations towards all stakeholder groups and concerned the majority of aspects of the company's activity. On the other hand, promotional programmes were defined as single actions targeted at selected stakeholder groups, e.g. consumers to achieve specific short-term goals, such as increased sales.

Also, research concerning other consumer reactions shows that various social initiatives affect consumer attitudes towards companies taking such actions to a different extent. For example, in a study by Van den Brink, Odekerken-Schroder and Pauwels (2006), it was shown that strategic initiatives, to a larger extent, affect consumer loyalty towards a brand than tactical actions. Four criteria were adopted for the division of initiatives into strategic and tactical ones: the consistency of the social problem with the company's profile, the duration of the initiative, the value of the assistance provided and the involvement of the company's management in assistance-related actions.

On the basis of the literature review presented above, the following conclusions can be drawn:

Firstly, undertaking social initiatives may lead to both improvement and deterioration in the attitudes towards a company.

Secondly, negative information about the company's social involvement has a stronger impact on consumer attitudes than positive information of this kind.

Thirdly, not all social initiatives influence attitudes towards a company to the same degree. However, we do not know exactly how individual structural elements of social initiatives affect consumer reactions. Neither in the research conducted by Prisch, Gupta \& 
Grau (2007), nor in the study by Van den Brink, Odekerken-Schroder \& Pauwwels (2005) was the impact of individual elements of social initiatives taken into account (e.g. the duration of such a programme).

Fourthly, the majority of the research so far was performed using students mostly in the United States, a country which is culturally significantly different from Poland.

\section{Research Methodology}

The scientific aim, i.e. an attempt to answer the question whether social initiatives affect consumer attitudes towards the company, which implements them, and which elements are of significant importance in this influence, was achieved by conducting an empirical study. Such a research method was selected because it ensures a significant control over the variables under analysis (e.g. Babbie, 2007, p. 246) and it has been widely used in similar studies (e.g. Creyer \& Ross 1997; Prabu, Kline \& Yang 2005).
For the purpose of the study, six scenarios of social initiatives undertaken by a food sector company were devised. The scenarios were prepared in the form of short descriptions of social initiatives implemented in the town, in which the research was performed. The afore-mentioned scenarios were constructed in the same way, they differed only in respect of four structural elements including: the subject - the social problem, which the company is involved to solve; the form of support - i.e. how the company provides assistance during the initiative, the duration of the initiative, the value of the assistance provided and cooperation with a non-profit entity (Table 1).

The subject of the social initiatives was considered in terms of its consistency with the company's activity. The problem of malnutrition among children and teenagers was selected as a consistent subject, and the problem of juvenile delinquency as a non-consistent subject. Such choices were made on the basis of pilot studies previously performed in a group of students.

Table 1. Social initiative scenarios used in the research

\begin{tabular}{|l|l|}
\hline Scenario number & Structural elements of the initiative \\
\hline 1 & $n D+P+K$ \\
\hline 2 & $D+P+K$ \\
\hline 3 & $n D+K o m p .+K$ \\
\hline 4 & $D+$ Kompl. + K \\
\hline 5 & D + Kompl. + Dł \\
\hline 6 & D + Kompl. + Dł + Nonprofit \\
\hline
\end{tabular}

D - high level of consistency, nD - low level of consistency, Dł - long-term programme, K- short-term programme, P- pecuniary support, Kompl. comprehensive support, Non-profit - cooperation with a non-profit entity

A programme lasting for a period of up to a year was considered a short-term program, while one lasting for over three years was regarded as a long-term programme. The support granted was either financial or comprehensive - including, apart from funds, material help, advice and involvement of the company's employ- ees in volunteering activity. If the company cooperated with a non-profit entity, an appropriate statement was added to the description of a social initiative.

The food sector was selected because the highest percentage of Polish consumers declares that they take into consideration the social involvement of companies 
while shopping (Grzegorzewska-Ramocka, 2005, p. 269). Products of the selected company are generally available in the majority of grocery shops. The aforementioned company was selected also because of its involvement in various charities, which increased the credibility of the scenarios.

The scenarios also contained a statement about the amount of the support granted. The value of the support was the same in all cases and it amounted to PLN 100,000 . Additionally, to attract the respondents' attention to the structural elements of social initiatives, a summary was added to each of the descriptions, in which the characteristic features of the presented initiatives were listed once again ${ }^{3}$.

\section{Measurement of the attitudes towards the company}

The measurement of the attitude towards the company was performed using the tool described in a study by Lafferty, Goldsmith and Hult (2004). This tool consisted of three seven-degree scales, the ends of which were marked with the following pairs of opposite adjectives: $\operatorname{good}=7 /$ bad $=1$, favourable $=7 /$ unfavourable $=$ 1 , positive $=7 /$ negative $=1$. It was the respondents' task to indicate three numbers, which most accurately reflected their feelings about the company under analysis. The internal consistency of the series of scales constructed in this way was determined by Cronbach's alpha to be 0.94 .

\section{Data analysis procedure}

The data analysis procedure included the so-called preliminary statistical description and statistical significance tests of differences between the mean values. The preliminary statistical description included an analysis of basic parameters, such as the arithmetic mean, the standard deviation and the maxima and minima. At this stage also, compliance with a normal distribution and the uniformity of variances were also examined.

The analysis of compliance with a normal distribution was performed using the so-called directional statistics, i.e. skewness and kurtosis. Skewness shows the degree of asymmetry of the probability distribution, while kurtosis makes it possible to assess the level of the distribution flattening. For a normal distribution, both values have the value of zero. The degree of the deviation from the afore-mentioned parameters constitutes the basis for the assessment of deviation from the normal distribution (Stanisz, 2006, pp. 125-126).

The research of variance uniformity of the index measuring the degree of favourability of the attitude towards the company between individual groups was performed using Levene's test (Koronacki \& Mielniczuk, 2004, p. 328)

First, it was attempted to use parametric tests ${ }^{4}$ to examine the significance between the mean values due to their greater power. However, such methods can be used only if the distribution of the variables under analysis is normal and if the variances are uniform (e.g. Brzeziński, 1999). In a situation when one of the aforementioned assumptions is not met, non-parametric tests were used for the verification of the hypotheses. Such a procedure is commonly accepted in social sciences (e.g. Francuz \& Mackiewicz, 2007, p. 421).

The Kruskal-Wallis test was used for hypotheses, in which more than two groups were compared. In the afore-mentioned test, the zero hypothesis means that the values of cumulative distribution functions of the variable under analysis in all groups amount to $\mathrm{H} 0$ : $\mathrm{F} 1(\mathrm{x})=\mathrm{F} 2(\mathrm{x})=\mathrm{Fk}(\mathrm{x})$. The alternative hypothesis, on the other hand, shows that significant differences occur in at least one pair of cumulative distribution functions $\mathrm{H1}$ : $\mathrm{Fi}(\mathrm{x}) \mathrm{Fj}(\mathrm{x})$

$$
H=\frac{12}{n(n+1)} \sum_{i=1}^{k} \frac{T_{i}^{2}}{n_{i}}-3(n+1)
$$

where: $\mathrm{T}_{\mathrm{i}}$ - means the sum of ranks in group $\mathrm{i}$, $\mathrm{n}$ - the total number of observations, $\mathrm{k}$ - the number of compared groups.

In the test, the zero hypothesis was rejected when the empirical probability value for the statistics $\mathrm{H}$ with $\mathrm{k}-1$ degrees of freedom was lower than the critical value a (Domański, 1990, pp. 147-148).

All calculations for the purpose of the present study were prepared using the Statistica 8.0 software.

\section{Research performance}

The research was conducted using a random sample of consumers. 500 addresses were drawn from the resources of the Local Database of the Lublin Provincial Office. Next, the afore-mentioned group was also randomly divided into seven groups: six experimental 
groups and one control group. The respondents from the experimental groups received information that the company undertakes a specific social programme, while the subjects from the control group did not receive such information.

The research was performed using a questionnairebased interview at the respondents' places of residence. First, the interviewer presented short information about the research. Next, the respondents were asked to read short information about a particular social initiative. Next, questions concerning the attitude towards the company, among other things, were asked.

\section{Research sample}

231 persons participated in the study, which constitutes $46.2 \%$ of the drawn sample. The percentage of respondents in the individual groups ranged from $44.29 \%$ to $48.57 \%$. The percentage of women among of the respondents was $70 \%$, while men constituted approximately $30 \%$ of the research participants. It is worth reminding here that the research was targeted at persons, who most often shop for groceries. Such a considerable share of women taking part in the study can be accounted for by the fact that it is usually women, who do this kind of shopping.

In terms of education, the structure of the sample is the following: $40.7 \%$ of the respondents had higher education, $45.0 \%$ of the respondents had secondary education, while $9.5 \%$ of the respondents had completed vocational education and only $5.2 \%$ of the respondents had only primary education. The samples under analysis included persons from all age groups. Approximately $50 \%$ of the respondents were aged below 50 , while the remaining respondents were older.

\section{Results of the Research}

The assessment of social initiatives undertaken by a company on consumer attitudes towards it was performed on the basis of the comparison of the mean values of the indices measuring these attitudes in the groups taking part in the experiment.

The index for the measurement of consumer attitudes towards the company was created by adding points from the three seven-degree scales and it could assume values ranging from 3 to 21 . The actual percentage measuring the respondents' attitude towards the company ranged from 5 to 21 points.
The index value was interpreted in such a way that its higher values meant a more favourable consumer attitude towards the company.

In the comparison of the average values of the index measuring the attitude towards the company, it is worth noting that its highest value was recorded in the control group $(M=17.30$; $S D=3.14)$, while its lowest value was recorded in group $2(\mathrm{M}=14.24 ; \mathrm{SD}=3.48)$. This shows that giving information about undertaking an additional initiative by the company certainly did not lead to a more favourable consumer attitude towards this entity. Additionally, the attitude towards the company under analysis may have deteriorated and to verify this, an analysis of statistical significance between the mean values was performed at the next stage. Detailed data concerning the mean values of the index measuring the attitude towards the company are presented in Table 2.

To select appropriate statistics to verify the statistical significance of the differences between the groups, an analysis of the consistency of the distribution of the index with the normal distribution and an analysis of the uniformity of variances were performed.

The analysis of consistency with the normal distribution was performed using the skewness and kurtosis coefficients.

The analysis of the skewness coefficients showed that the distribution of the index measuring the attitude towards the company for all the groups was characterised by a slight left-sided asymmetry. This means that the respondents most frequently showed a more favourable attitude towards the company than the mean value implied. In the division into groups, the left-sided asymmetry was also predominant, the right-sided asymmetry was observed only in Group 3. It is worth noting that the kurtosis was negative in the majority of the groups - apart from Group four, which means that the analysed distribution was less concentrated than in the case of a normal distribution. Detailed data concerning the skewness and kurtosis coefficients are presented in Table 3.

The analysis of the uniformity of variances was performed using Lavene's test. The test showed that there existed a statistically significant difference between the variances of at least two groups $(\mathrm{F}(6,225)=0.591 ; \mathrm{p}$ $=0.738$ ). 
Table 2. The mean, the standard deviation, the minima and maxima of the index measuring the attitude towards the company in groups

\begin{tabular}{|c|l|c|c|c|c|}
\hline Group number & $\begin{array}{l}\text { Structural elements of the } \\
\text { initiative }\end{array}$ & Mean value & $\begin{array}{c}\text { Standard } \\
\text { deviation }\end{array}$ & Minimum & Maximum \\
\hline 1 & $\mathrm{nD}+\mathrm{P}+\mathrm{K}$ & 15.23 & 3.222 & 8 & 21 \\
\hline 2 & $\mathrm{D}+\mathrm{P}+\mathrm{K}$ & 14.24 & 3.482 & 6 & 21 \\
\hline 3 & $\mathrm{nD}+$ Komp. + K & 15.31 & 3.383 & 8 & 21 \\
\hline 4 & $\mathrm{D}+$ Komp. + K & 17.18 & 3.877 & 5 & 21 \\
\hline 5 & D + Komp. + Dł & 16.32 & 2.833 & 12 & 21 \\
\hline 6 & D + Komp. Dł + Non-profit & 16.85 & 3.594 & 9 & 21 \\
\hline 7 & Control group All groups & 17.30 & 3.135 & 12 & 21 \\
\hline & & & & 5 & 21 \\
\hline
\end{tabular}

$\mathrm{D}$ - high level of consistency, $\mathrm{nD}$ - low level of consistency, Dt - long-term programme, $\mathrm{K}$ - short-term programme, $\mathrm{P}$ - pecuniary support, Kompl. comprehensive support, Non-profit - cooperation with a non-profit entity

Table 3. Skewness and kurtosis coefficients together with standard errors of the index measuring the attitude towards the company - division into groups

\begin{tabular}{|c|l|c|c|c|c|}
\hline Group number & $\begin{array}{l}\text { Structural elements of the initia- } \\
\text { tive }\end{array}$ & $\begin{array}{c}\text { Skewness coef- } \\
\text { ficient }\end{array}$ & $\begin{array}{c}\text { Standard error } \\
\text { of skewness }\end{array}$ & Kurtosis & $\begin{array}{c}\text { Standard error } \\
\text { of kurtosis }\end{array}$ \\
\hline 1 & $\mathrm{nD}+\mathrm{P}+\mathrm{K}$ & -0.128 & 0.421 & -0.109 & 0.821 \\
\hline 2 & $\mathrm{D}+\mathrm{P}+\mathrm{K}$ & -0.098 & 0.409 & -0.048 & 0.798 \\
\hline 3 & $\mathrm{nD}+$ Komp. + K & 0.144 & 0.414 & -0.673 & 0.809 \\
\hline 4 & $\mathrm{D}+$ Komp. + K & -1.226 & 0.409 & 1.807 & 0.798 \\
\hline 5 & $\mathrm{D}+$ Komp. + Dł & -0.144 & 0.421 & -0.870 & 0.821 \\
\hline 6 & D + Komp. + Dł + Non-profit & -0.418 & 0.403 & -1.023 & 0.788 \\
\hline 7 & Control group All groups & -0.686 & 0.388 & -0.753 & 0.759 \\
\hline
\end{tabular}

$\mathrm{D}$ - high level of consistency, nD - low level of consistency, Dł - long-term programme, K- short-term programme, P- pecuniary support, Kompl. comprehensive support, Non-profit - cooperation with a non-profit entity

Due to considerable deviations from the normal distribution in Groups 4 and $6^{5}$ and the failure to meet the uniformity of variances assumption between average values of indices measuring the attitude towards the company, the Kruskal-Wallis rank test was used. The test showed that there existed a statistically significant difference between the distributions of the variable under analysis in at least two groups $(\mathrm{H}(6, \mathrm{~N}=$ 231) $=23.825 ; \mathrm{p}=0.001)$.

To verify the statistical significance of the differences between the individual groups, the empirical probability values were calculated for bilateral multiple comparisons of the Kruskal-Wallis test. The summary of these calculations is presented in Table 4.

An analysis of differences between the distribution of the attitudes in the individual groups showed that significant discrepancies existed only between the attitude in Group 2 and the attitude in Groups 4, $6^{6}$ and 7. It is particularly interesting to note that the attitude of the consumers from Group 2 turned out to be significantly less favourable than the attitude of the consumers from Group 7 - the control group. It should be reminded here 
Table 4. Values for multiple comparisons (bilateral) of the index measuring the attitude towards the company - division into groups

\begin{tabular}{|c|c|c|c|c|c|c|c|}
\hline $\begin{array}{l}\text { Group } \\
\text { number }\end{array}$ & $\begin{array}{c}1 \\
R: 98.677^{* *}\end{array}$ & $\begin{array}{c}2 \\
R: 81.379\end{array}$ & $\begin{array}{c}3 \\
R: 99.563\end{array}$ & $\begin{array}{c}4 \\
R: 139.82\end{array}$ & $\begin{array}{c}5 \\
R: 117.84\end{array}$ & $\begin{array}{c}6 \\
R: 130.88\end{array}$ & $\begin{array}{c}7 \\
R: 139.15\end{array}$ \\
\hline 1 & & 1.000 & 1.000 & 0.291 & 1.000 & 1.000 & 0.270 \\
\hline 2 & 1.000 & & 1.000 & $0.008^{*}$ & 0.612 & 0.051 & $0.006^{*}$ \\
\hline 3 & 1.000 & 1.000 & & 0.319 & 1.000 & 1.000 & 0.297 \\
\hline 4 & 0.291 & $0.008^{*}$ & 0.319 & & 1.000 & 1.000 & 1.000 \\
\hline 5 & 1.000 & 0.612 & 1.000 & 1.000 & & 1.000 & 1.000 \\
\hline 6 & 1.000 & 0.051 & 1.000 & 1.000 & 1.000 & & 1.000 \\
\hline 7 & 0.270 & $0.006^{*}$ & 0.297 & 1.000 & 1.000 & 1.000 & \\
\hline
\end{tabular}

Source: own study

that the control group respondents did not receive any information about the company's social initiative. The results obtained can be accounted for by the fact that the respondents from Group 2 received a description of the social programme, which probably was not consistent with the activity conducted by the company to date.

An analysis of the results obtained also shows that the respondents' attitude from none of the experimental groups was significantly more favourable than the attitude of the control group consumers. This means that information about undertaking another social initiative by a company did not lead directly to a more favourable consumer attitude towards it.

\section{Conclusions}

Contrary to the expectations, no positive influence of the information about the company's pro-social involvement on the respondents' attitude towards it was shown. The lack of the afore-mentioned influence may have resulted from the good reputation of the company selected to implement social initiatives. The company identified as the implementer of social initiatives is known both for its high quality products and its involvement in charitable activity. As a result, the respondents' attitude towards it was already favourable
- even without giving information about undertaking a social initiative by this company. The information about the undertaken initiative was just additional information about it. It is possible that such information would have improved the attitudes towards a company with an average reputation. It is also possible that a company's greater and longer-lasting involvement in social initiatives will lead to improved attitudes towards this company. A longitudinal study covering a longer period of time would have to be performed to verify this hypothesis.

While discussing the results obtained, it is also worth paying attention to a significant deterioration of the attitude towards the company in Group 2. The initiative scenario in this group informed that the company was going to devote a certain amount of funds to this initiative only on a single occasion. In reality, the company under analysis is known for a broader range of support, which includes, among other things, donation of food products and organisation of food drives. Thus, it is possible that the social initiative presented to the respondents did not meet their expectations and the contrast effect occurred.

As regards the contrast effect, it also occurred, among other things, in the research by Brown \& Dacin 
(1997), which has already been quoted in this study; however, it only applied to the relationship between the company's competences and the evaluation of the new product. The research conducted shows that the contrast effect may occur only in the case of a company's social responsibility and newly undertaken social initiatives. Further in-depth research on consumer reactions to social initiatives is worth conducting in this area.

Finally, it should be noted that due to the selection of a large food sector company enjoying a good reputation to be the implementer of social initiatives, the results obtained may be prudently generalised only to similar companies.

\section{References}

1. Babbie, E. (2007). Badania społeczne w praktyce. Warsaw: Wydawnictwo Naukowe PWN.

2. Becker - Olsen, K.L., Cudmore, A.B. \& Hill, R.P. (2006).The impact of perceived corporate social responsibility on consumer behaviour. Journal of Business Research 59(1), 46-53.

3. Bhattacharya, C.B. \& Sen, S. (2004). Doing better at doing good: When, why, and how consumers respond to corporate social initiatives. California Management Review 40(1), 9-24.

4. Bhattacharya, C.B. \& Sen, S. (2003). The effect of corporate partnership on consumer reactions to non-profits. Advances in Consumer Research, 30(1), 324.

5. Bhattacharya, C.B., Korschun, D. \& Sen, S. (2009). Strengthening stakeholder-company relationships through mutually beneficial corporate social responsibility initiatives. Journal of Business Ethics, 85(2), 257-272.

6. Brown, T.J. \& Dacin, P.A. (1997). The company and the product: Corporate associations and consumer product response. Journal of Marketing 61(1): 68-84

7. Brzeziński, J. (1999). Metodologia badań psychologicznych. Warsaw: Wydawnictwo Naukowe PWN.

8. Creyer, E.H. \& Ross, W.T. (1997). The influence of firm behavior on purchase intention: do consumers really care about business ethics? Journal of Consumer Marketing, 14(6), 173-185.

9. Cui, Y., Trent, E.S., Sullivan, P.M. et al. (2003).
Cause-related marketing: How generation Y responds. International Journal of Retail \& Distribution Management, 31(6), 310-320.

10. Domański, Cz. (1990). Testy statystyczne. Warsaw: Państwowe Wydawnictwo Ekonomiczne.

11. Francuz, P. \& Mackiewicz, R. (2007). Liczby nie wiedza skąd pochodza: przewodnik po metodologii i statystyce nie tylko dla psychologów. Lublin: Wydawnictwo KUL.

12. Grzegorzewska - Ramocka, E. (2005). Koncepcja społecznej odpowiedzialności przedsiębiorstwa $w$ marketingu strategicznym. Kielce: Wydawnictwo Politechniki Świętokrzyskiej.

13. Huck, S.W. (2009). Reading Statistics and Research. Boston: Pearson Ally and Bacon.

14. Ipsos. (2003). Postawy wobec społecznej odpowiedzialności biznesu. Available at: www.ipsos.pl/3_2_009a.pdf

15. Koronacki, J. \& Mielniczuk, J. (2004). Statystyka dla studentów kierunków technicznych i przyrodniczych. Warszawa: Wydawnictwa Naukowo - Techniczne.

16. Kotler, P. \& Lee, N. (2004). Best of breed. When it comes to gaining a market edge while supporting a social cause, 'corporate social marketing' leads the pack. Stanford Social Innovation Review, 1(4), 14-23.

17. Lafferty, B.A., Goldsmith, R.E. \& Hult, G.T. (2004). The impact of the alliance on the partners: A look at cause-brand alliances. Psychology \& Marketing, 21(7), 509-531.

18. Lafferty, B.A. \& Goldsmith, R.E. (1999). Corporate credibility's role in consumer's attitudes and purchase intentions when a high versus a low credibility endorser is used in the ad. Journal of Business Research, 44(2), 109-116.

19. Maison, D. \& Wasilewski, P. (2008). Propaganda dobrych serc - czyli rzecz o reklamie społecznej. Kraków: Agencja Wasilewski.

20. Marin, L. \& Ruiz, S. (2007). I need you too! Corporate identity attractiveness for consumers and the role of social responsibility. Journal of Business Ethics, 77(3), 245-260

21. Menon, S. \& Kahn, B.E. (2003). Corporate sponsorships of philanthropic activities: When do they impact perception of sponsor brand? Journal of Consumer Psychology, 13(3), 316-327.

22. Mohr, L.A. \& Webb, D.J. (2005). The effects of cor- 
porate social responsibility and price on consumer responses. The Journal of Consumer Affairs, 39(1), 121-147.

23. Prabu, D., Kline, S. and Yang, D. (2005). Corporate social responsibility practices, corporate identity, and purchase intention: A dual-process model. Journal of Public Relations Research, 17(3), 391-313.

24. Prisch, J., Gupta, S. \& Grau, S.L. (2007). A framework for understanding corporate social responsibility programs as a continuum: An exploratory study. Journal of Business Ethics, 70(2), 125-140.

25. Salmones, G., Crespo, A. and Bosque, I. (2005). Influence of corporate social responsibility on loyalty and valuation of services. Journal of Business Ethics, 61(4), 369-385.

26. Sen, S. \& Bhattacharya, C.B. (2001). Does doing good always lead to doing better? Consumer reaction to corporate social responsibility. Journal of Marketing Research, 38(2), 225-243.

27. Sen, S., Bhattacharya, C.B. \& Korschun, D. (2006). The role of corporate social responsibility in strengthening multiple stakeholder relationships: A filed experiment. Journal of the Academy of Marketing Science, 34(2), 158-166.

28. Smith, C. (2003) Corporate social responsibility: WHETHER OR HOW? California Management Review, 45(4), 52-76.

29. Stanisz, A. (2006) Przystępny kurs statystyki. Tom I. Kraków: StatSoft Polska.

30. Van den Brink, D., Odekerken - Schroder, G. \& Pauwels, P. (2006). The effect of strategic and tactical cause-related marketing on consumer' brand loyalty. Journal of Consumer Marketing, 23(1), 15-25.

31. Vogel, D.J. (2005). Is there a market for virtue? The business case for corporate social responsibility. California Management Review, 47(4), 19-45.

32. Yoon, Y., Gürhan-Canli, Z. \& Schwarz, N. (2006). The effect of corporate social responsibility (CSR) activities on companies with bad reputations. Journal of Consumer Psychology, 16(4), 377-390.

33. Yoon, Y. and Gürhan-Canli, Z. (2003). Negative consequences of doing good: The effects of perceived motives underlying corporate social responsibility. Advances in Consumer Research, 30(1), 323-324.

34. Zrałek, J. (2007). Konsumenci wobec public rela- tions - komunikacyjne uwarunkowania zachowań nabywczych. Katowice: Wydawnictwo Akademii Ekonomicznej w Katowicach.

\section{Notes}

1 Some researchers used the term corporate evaluation (e.g. Brown \& Dacin, 1997; Sen \& Bhattacharya 2001), while others used the term company attitude (Bhattacharya \& Sen, 2003; Prisch, Gupta \& Grau, 2007; Becker - Olsen, Cudmore \& Hill, 2006). However, both cases apply to the general attitude towards a company understood as the consumer inclination to more or less favourable evaluation of such a company.

2 The influence of the competences on the consumer attitudes towards the company was more than twice as high as the influence of the perceived social responsibility.

3 Such a solution was used by analogy to control charts used by Brown and Dacin (1997).

4 The use of the variance analysis and t-tests was also considered in this article. However, as the basic assumptions required for these tests were not met, they were not applied. Therefore, they have not been described in greater detail.

5 Cases, in which the values of the skewness or kurtosis coefficients were higher than the absolute value of one, were assumed to be considerable deviations from the normal distribution (Huck, 2009, p. 29).

6 For Group 6, the level of empirical probability only slightly exceeded the critical significance level (0.051 compared to 0.05); therefore, the identified differences were regarded as significant.

\section{Acknowledgements}

The results presented constitute a part of the project funded by the Ministry of Science and Higher Education within the grant pursuant to Agreement No. 0974/B/ H03/2008/35. 